\title{
Post viral upper and lower motor neuron injuries
}

Figure 1 Cortical and deep gray matter injuries

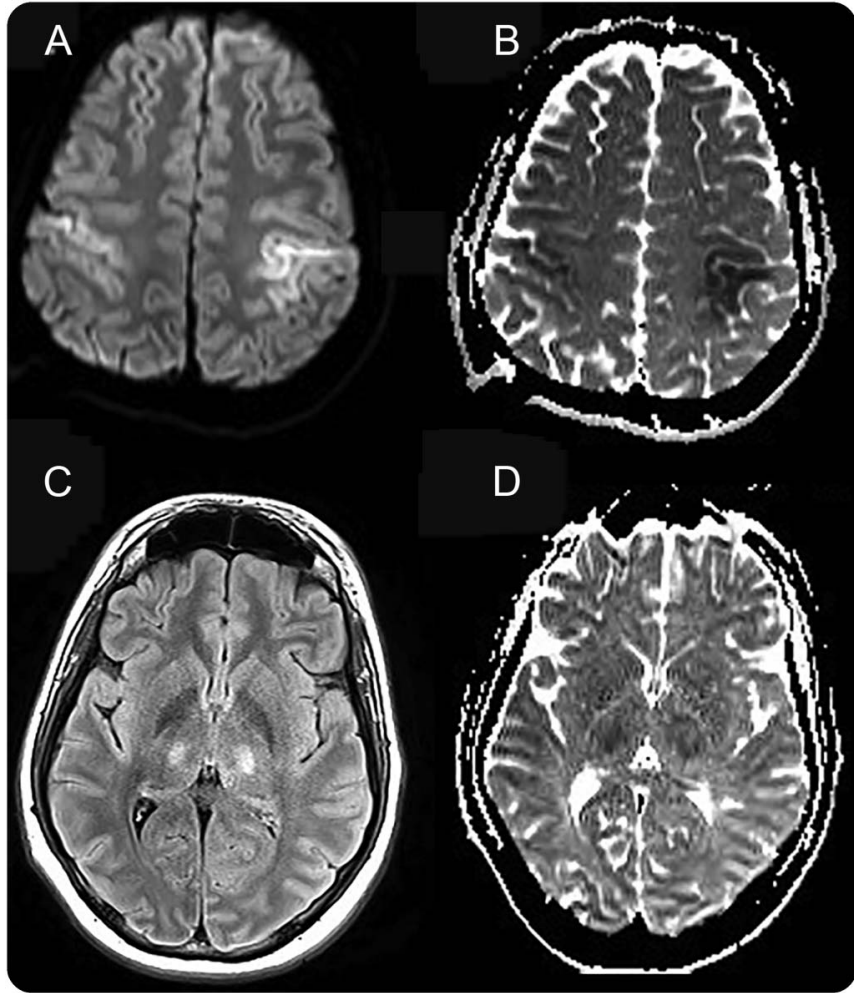

Cerebral MRI shows bilateral perirolandic cortex hyperintensities on diffusion-weighted imaging (A) matching with hypointensities on apparent diffusion coefficient (ADC) map (B). Bilateral thalamic hyperintensities were seen on fluidattenuated inversion recovery sequence (C) with restricted diffusion on ADC map (D).

A 20-year-old man presented with subacute dysarthria, along with bilateral facial and brachial palsy, after a febrile odynophagia. Initially brisk, his upper limb deep tendon reflexes decreased with muscle wasting concerning the C5-T1 myotomes. MRI showed bilateral prefrontal gyri and thalami lesions with anterior cervical spinal cord lesion (figures 1 and 2). Upper limb lower motor neuron involvement was confirmed by EMG. CSF analysis showed lymphocytic pleiocytosis, elevated protein, and normal glucose levels. Epstein-Barr virus (EBV) serology revealed acute infection with the presence of viral capsid antigen (VCA) immunoglobulin $\mathrm{M}$ and VCA immunoglobulin $\mathrm{G}(\mathrm{IgG})$, in the absence of Epstein-Barr nuclear antigen-1 IgG. EBV DNA load was increased in blood and CSF. Other investigations including HIV screening remained negative. Simultaneous upper and lower motor neuron injury, well-described in HIV, is an unusual finding in EBV infection. ${ }^{1}$

Elisa De La Cruz, Aude Metzger, MD, PhD, Pierre Braquet, MD, Nicolas Gaillard, MD, Guillaume Taieb, MD

From the Departments of Neurology (E.d.l.C., A.M., N.G., G.T.) and Infectious Diseases (P.B.), University Hospital of Montpellier Gui de Chauliac, France.

Author contributions: E. De La Cruz: drafting and revision of manuscript, acquisition of data. Dr. Metzger: critical revision of manuscript for intellectual content. Dr. Braquet: critical revision of manuscript for intellectual content. Dr. Gaillard: analysis and interpretation of data, critical revision of manuscript for intellectual content. Dr. Taieb: analysis and interpretation of data, critical revision of manuscript for intellectual content. 


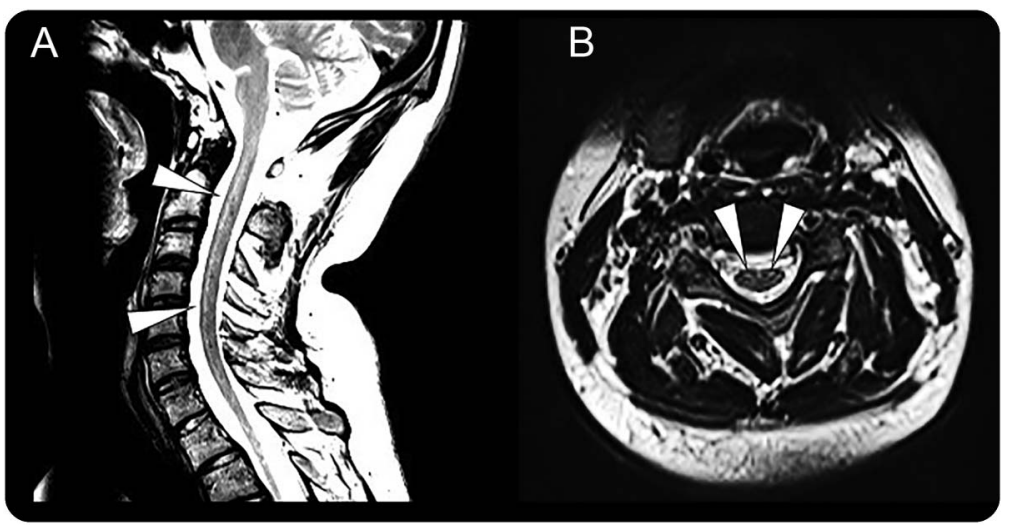

Sagittal (A) and axial (B) T2-weighted images show anterior horn cells hyperintensities (arrowheads).

Study funding: No targeted funding reported.

Disclosure: The authors report no disclosures relevant to the manuscript. Go to Neurology.org for full disclosures.

Correspondence to E. De La Cruz: elisa@sdlc.ca

1. Verma A, Berger JR. ALS syndrome in patients with HIV-1 infection. J Neurol Sci 2006;240:59-64.

\section{WriteClick ${ }^{\circledR}$ rapid online correspondence}

Have a comment on a recent $N e u r o l o g y{ }^{\circledR}$ article you would like to share? Now it is easier and more convenient. Neurology.org has launched WriteClick on the home page and sidebars of each article to encourage remarks and debate among users.

WriteClick is restricted to comments about studies published in Neurology within the last eight weeks.

Learn more at Neurology.org/letters

\section{Four Days That Will Change Your Life}

The American Academy of Neurology is accepting applications from AAN members for the 2018 Palatucci Advocacy Leadership Forum, being held from May 17-20, 2018. The application deadline is December 11, 2017.

The AAN established this award-winning leadership program in 2003 to provide effective advocacy training unavailable elsewhere, because neurologists are the best advocates for our profession and our patients. The skills you develop during this unforgettable weekend can enhance your career and revitalize your passion for neurology. Learn more and apply at AAN.com/view/PALF. 


\section{Neurology}

\section{Post viral upper and lower motor neuron injuries \\ Elisa De La Cruz, Aude Metzger, Pierre Braquet, et al.}

Neurology 2017;89;1928-1929

DOI 10.1212/WNL.0000000000004601

This information is current as of October 30, 2017

\section{Updated Information \&} Services

\section{References}

Subspecialty Collections

Permissions \& Licensing

Reprints including high resolution figures, can be found at: http://n.neurology.org/content/89/18/1928.full

This article cites 1 articles, 0 of which you can access for free at: http://n.neurology.org/content/89/18/1928.full\#ref-list-1

This article, along with others on similar topics, appears in the following collection(s):

Amyotrophic lateral sclerosis

http://n.neurology.org/cgi/collection/amyotrophic_lateral_sclerosis_

Information about reproducing this article in parts (figures,tables) or in its entirety can be found online at:

http://www.neurology.org/about/about_the_journal\#permissions

Information about ordering reprints can be found online:

http://n.neurology.org/subscribers/advertise

Neurology ${ }^{\circledR}$ is the official journal of the American Academy of Neurology. Published continuously since 1951, it is now a weekly with 48 issues per year. Copyright (O 2017 American Academy of Neurology. All rights reserved. Print ISSN: 0028-3878. Online ISSN: 1526-632X.

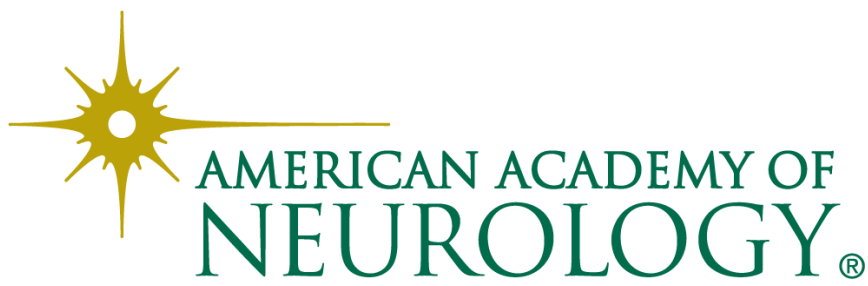

